\title{
Subjektivní vnímání proměny role ředitele školy a obtížné prvky výkonu této profese v současné době 1
}

\author{
Václav Trojan a , Zuzana Svobodová ${ }^{\mathrm{b}}$ \\ ${ }^{a}$ Univerzita Karlova, Pedagogická fakulta, \\ Ústav profesního rozvoje pedagogických pracovníků ve školství \\ b Univerzita Karlova, Pedagogická fakulta, Katedra andragogiky a managementu vzdělávání
}

Redakci zasláno 10.1.2019 / upravená verze obdržena 3. 6. 2019 /

/ k uveřejnění přijato 4. 6. 2019

\begin{abstract}
Abstrakt: Studie se zabývá subjektivním vnímáním proměny ředitelské role po roce 2000 a reflektuje zároveň obtížné prvky výkonu této profese v současné době. V teoretické části vymezuje zásadní mezníky, které nově definovaly autonomní pozici českých škol a s tím i autonomní roli jejich ředitelů. Popisuje strategické dokumenty, které cílily na standardizaci vstupního a průběžného vzdělávání a podpory ředitelů škol, což nikdy nebylo systémově uskutečněno. Výsledky kvalitativního výzkumu založeného na datech získaných z ohniskové skupiny představují subjektivní názory zkušených ředitelů pražských základních a středních škol na vývoj jejich role, popisují problémy, které ředitelé vnímají, a trendy, které dále určují jejich práci. Ředitel školy je základním faktorem úspěchu každé školy a jeho postavení je vzhledem k neobvykle vysoké míře kurikulární i zdrojové autonomie české školy specifické. Ukazuje se, že postupným vývojem a přidáváním dalších povinností a zároveň neexistující systémovou podporou ředitele byla vytvořena náročná situace, ve které současní ředitelé škol vnímají řadu problémů, jako je například nedostatek času na řízení pedagogického procesu, nedostatek pracovníků, nadbytek zbytečných byrokratických činností a nedůvěra v systém jako takový.
\end{abstract}

Klíčová slova: ředitel školy, pedagogické vedení, pedagogický proces, standard ředitele

Studie si klade za cíl popsat proměňující se roli ředitele školy a její subjektivní vnímání samotnými řediteli a ředitelkami v období po roce 2000 , a to konkrétně na základě popisu změn ve vzdělávací politice a zároveň pohledem zkušených ředitelů škol. Zásadní změnu pro roli ředitele školy představovala reforma státní správy v roce 2000, postupné posilování autonomie škol,

1 Studie vznikla za podpory projektu UK Progres Q17.

https://doi.org/10.5817/PedOr2019-2-203 
a tím i autonomní role jejich statutárních zástupců. K postupnému ukotvování silné ředitelské role docházelo od ledna 2005 v souvislosti s platností a účinností nového školského zákona. Aktéři vzdělávací politiky se dlouhodobě snaží nastavit systémovou podporu vedení škol, definovat jejich kariérní stupně, vymezit vzdělávání a jejich další rozvoj a celkově standardizovat a systémově ukotvit tuto významnou roli v českém školství. Faktem je, že k žádanému ukotvení dosud nedošlo a podpora je ředitelům poskytována jednotlivými snahami či izolovanými iniciativami různých státních i nestátních organizací. Předkládaný text se tedy vyrovnává také s aktuální problematikou v minulosti připravovaných a nerealizovaných snah o ukotvení role ředitele školy (napřr. Bílá kniha, Strategie 2020, snaha o kariérní řád).

V teoretické části textu se věnujeme - kromě popisu specifické role ředitele, který je zároveň lídrem, manažerem i vykonavatelem procesu - významným mezníkům a dokumentům, $v$ nichž byla patrná snaha ředitelskou roli popsat a standardizovat. Rovněž popisujeme klíčové změny, které měly dopad př́mo na fungování škol (např. kvalifikovanost pedagogických pracovníků). Hovoříme-li o řediteli školy, je nutné vymezit rovněž pojem škola jako takový. Pojetí školy totiž do značné míry určuje paradigma školského managementu i chápání rolí ředitelů škol (Trojan \& Trunda, 2018). V tomto textu se přikláníme k pojetí školy jako specifické organizace (např. Pol et al., 2004), ve které dochází ke specifické činnosti, která je u ředitelů škol a školských organizací obvykle nazývána rrízením pedagogického procesu (Trojan \& Trunda, 2018).

Najít jednotný teoretický základ pedagogického vedení školy se jeví jako relativně nesnadný úkol, nebot' př́stupy jednotlivých autorů jsou zaměřeny na různé aspekty této obsahově nejrozsáhlejší oblasti vedení školy. Blase a Blase (2000) ukazují, že jednotlivé pokusy vymezit pedagogické vedení školy lze dělit do tří hlavních tematických skupin. Pojetí patřící do první skupiny označují např. Blase a Blase (2000) jako normativní modely popisující vedení pedagogického procesu v podobě soupisu úkolů zaměřených na př́mou pomoc učitelům, na rozvoj týmů a vývoj a zdokonalování kurikula. Druhý typ studií se pokouší vymezit pedagogické vedení školy na základě toho, jaký vliv na učitelovu práci ve tř́ídě má chování lídrů škol, zejména pak ředitelů, v podobě například hospitací, vedení pedagogických porad apod. Třetí dominantní skupina je sycena příspěvky, $v$ nichž se snaží autoři propojit roli lídrů (ředitelů) škol přímo se vzdělávacími výsledky žáků a studentů. Pojetí spadající do pomyslné druhé a třetí skupiny jsou nezř́íka podporována 
také empirickými výzkumy. Je potřeba přitom dodat, že tyto okruhy nelze striktně a uměle oddělovat, jelikož jsou často provázané a navazující na sebe (Sedláček, 2011).

Ve výzkumné části představujeme výsledky kvalitativní studie názorů zkušených ředitelů základních a středních škol založené na metodě ohniskové skupiny, ve které jsme hledali odpověd' na hlavní výzkumnou otázku - Jak subjektivně vnímají zkušení reditelé proměnu své role v období po roce 2000? $\mathrm{S}$ řediteli jsme diskutovali vývoj vzdělávací politiky, legislativní změny, současné trendy, problémy a potřeby současné školy. Vnímáme, že tlak na změny ve vzdělávání a potažmo ve fungování škol je vlivem rostoucího tempa sociokulturních, technických a dalších změn stále větší, což ovlivňuje i roli ředitele školy (např. Kaarina \& Gonzales, 2011; Moree, 2013).

\section{1 Širší kontext problematiky}

Napříč vzdělávacími systémy různých zemí můžeme sledovat odlišnou míru autonomního postavení ředitele školy. Mezinárodní komparativní analýzy hodnotí tradičně autonomii škol ze dvou perspektiv: řízení zdrojů (finančních a personálních) a řízení vzdělávacích záležitostí (řízení kurikula). Na základě empirických zjištění lze dokladovat, že ředitelé škol jsou klíčovými aktéry změny ve vzdělávacích systémech (Bolam \& Van Wierigen, 1999; Briggs \& Coleman, 2007; Pont et al., 2008; Huber, 2009; Benhabani, 2011; Leithwood, Sun, \& Pollock, 2017). Řada empirických výzkumů a studií (Leithwood, 2005; Mulford, 2008; Obdržálek \& Polák, 2008; Robinson, Hohepa, \& Lloyd, 2009; Abari-Ibolya \& Baráth, 2010) argumentuje, že způsob a úroveň vedení školy jsou jedněmi ze zásadních činitelů ovlivňujících učení žáků, a tím i celkovou kvalitu a efektivitu školy (Leithwood, 2005; Pisoňová, 2014; Dvořák \& Trunda, 2017).

Ředitel je klíčovým pracovníkem každé české školy. Podle platného zákonného vymezení je odpovědný za všechny procesy ve škole, zejména za výběr, rozvoj a hodnocení pracovníků, za kvalitu výuky i za ekonomickou stránku školy, zároveň musí mít učitelskou kvalifikaci i odpovídající pedagogickou praxi. Již rámcový výčet oblastí odpovědnosti ředitele ukazuje na náročnost této role kombinující lídrovské a manažerské kompetence s odbornými pedagogickými znalostmi. Důsledky činností ředitele školy zasahují často velké množství lidí na dlouhou dobu (Trojan, 2016). V českých i v zahraničních pramenech je proto kladen důraz na profesionální př́ípravu (Schratz, 2011), 
na vzdělávání ředitelů a kultivaci jejich ředitelských kompetencí (Lhotková, Trojan, \& Kitzberger, 2012; Veteška, 2016). Postavení ředitele české školy je výjimečné rovněž v rámci zemí OECD. Vysoká hodnota kurikulární autonomie i autonomie využívání zdrojů (Trojan, 2011) je neobvyklá napříč vzdělávacími systémy a z této skutečnosti vyplývá silný tlak na jednotlivé ředitele škol i objem jejich povinností a odpovědnosti. Tradice českého pojetí ředitele jej spojuje s učitelem, je vyžadováno pedagogické vzdělání a odpovídající pedagogická praxe, po celou dobu práce ředitele zůstává pedagogickým pracovníkem s povinností přímého pedagogického působení na žáky.

Změna role a postavení managementu školy ve smyslu označení skupiny aktérů vzdělávání je vyjádřena změnou formulace očekávání toho, čeho by vedení školy mělo dosahovat (Pont et al., 2008). Nemění se ale jen obsah očekávání, nýbrž také jeho míra. Výzkumy ukazují, že podle veřejného mínění jsou ředitelé škol po ministerstvu školství druzí ve výčtu aktérů vzdělávání, od kterých se očekává, že budou přispívat k rozvoji školství (Černý et al., 2007).

V profesi ředitele školy se překrývají dvě typově různé pracovní činnosti dvou odborných směrů. V první řadě to je výchova a vzdělávání (ředitel musí v souladu se zákonem 563/2004 Sb. splňovat kvalifikační předpoklady učitele a naplňovat standard profesních kvalit učitele), za druhé jde o pedagogické vedení, jehož podstatou je způsobilost pro koordinaci školy a převzetí zodpovědnosti za tvorbu rozvojových strategií školy. Současné pracovní a kvalifikační vymezení ukotvuje ředitele škol ve dvou profesích současně. To je důsledkem tradičního vnímání postavení ředitele především jako učitele, který je jedním a zároveň „prvním“ z učitelského sboru (Dvořák, 2011). Nejen v zahraničí, ale i v České republice však v průběhu transformace státní správy (rozpad odvětvového řízení, přechod škol do právní subjektivity, kurikulární autonomie škol apod.) došlo k zásadní změně obsahu práce a rozšíření administrativní a provozní agendy, o kterou se musí ředitel školy starat vedle řízení pedagogického procesu a realizace vlastní výuky (Voda, 2015). Charakter práce ředitele školy se tak proměnil od řídícího učitele (Dvořák, 2011), resp. od pedagogického vedoucího školy, ke komplexnímu manažerovi (Pol, 2007).

Pokud bychom se v rámci širokého spektra profesních činností ředitele soustředili pouze na jádrovou oblast odvozenou od primárního účelu školy, tj. na oblast vzdělávání, přesněji ovlivňování vzdělávacích výsledků žáků, 
můžeme nalézt inspirace např v novozélandské studii (metaanalýze 26 mezinárodních studií), která prokázala evidentní souvztažnost mezi vedením školy (school leadership) a výsledky žáků (Robinson, Hohepa, \& Lloyd, 2009). Jiný př́stup k organizaci poznatků, jak leadership ovlivňuje učení žáků, nabídli Leithwood a kol. (2006), kteří vyjmenovali tři hlavní oblasti: vytyčování směru (utváření vize, konkretizace cílů a priorit, postulování vysokých výkonových nároků), rozvoj lidí (individualizovaná podpora a vlastní př́íklad) a rekonstrukce (redesigning) organizace ve smyslu rozvoje spolupráce a participace na rozhodování.

V posledních dekádách dochází ve vzdělávacích systémech $\mathrm{k}$ decentralizaci a zvyšování autonomie škol. Čím dál komplexnější a komplikovanější role ředitelů tak klade nároky na osoby, které tuto funkci zastávají. Proto jsou důležité nejen předpoklady (napřr. kvalifikace) pro výkon funkce ředitele, ale také rozvoj a udržování již získaných dovedností a sdílení zkušeností s dalšími řediteli (Kašparová et al., 2014). Je otázkou, zdali narůstající autonomie přináší řediteli větší sociální respekt, obdiv a uznání spojené s konkrétním sociálním statusem (Urban, 2017). Metaanalýzy faktorů ovlivňujících vzdělávací výsledky žáků ukazují, že kvalita učitelů a ředitelů ovlivňuje kvalitu vzdělávání mnohem více než jiné faktory (Leithwood et al., 2006; Hattie, 2011). Jakákoli vzdělávací reforma se tedy musí zaměřit na zvýšení kvality vyučování přímo ve trrídách - na schopnosti učitelů lépe vzdělávat a schopnosti ředitelů lépe řídit. To předpokládá kvalitní profesní vzdělávání orientované na skutečné potřeby učitelů a ředitelů. Profesní vzdělávání ředitelů být mnohem více orientováno na pedagogický leadership, tj. na to, jakým způsobem zvyšovat kvalitu vyučování (Veselý, 2013).

Právě nedostatečná podpora učitelů ze strany vedení školy je jedním z hlavních faktorů, které stojí za opouštěním učitelského povolání, především u učitelů v průběhu prvních pěti let praxe (Píšová \& Hanušová, 2016). Lze tedy předpokládat, že ředitelé hrají důležitou roli v samotném vývoji učitele, mohou pomáhat začínajícím učitelům ve zvládání jejich nové role, vést zkušenější učitele k dosažení role učitele-experta nebo usnadňovat učitelům na sklonku kariéry zvládání tohoto výrazného profesního a životního mezníku. To mimo jiné znamená, že by se ředitel měl dobře orientovat v možných fázích učitelova profesního i psychického vývoje (Lukas, 2009).

Základní požadavky na práci ředitele škol stanovuje zákon o pedagogických pracovnících (563/2004 Sb.), který určuje povinné manažerské vstupní 
vzdělání. Nicméně po jeho absolvování již nemá ředitel školy povinnost dalšího rozvoje v oblasti školského managementu. Povinnost dalšího vzdělávání má stanovenou jako všichni pedagogičtí pracovníci, nikoli jako vedoucí pedagogický pracovník (zákon 563/2004 Sb.).

Neoliberální pojetí funkce ředitele školy (Štech, 2007; Kaščák \& Pupala, 2012) hovoř́ící o řediteli jako o manažerovi jakékoli organizace je příčinou snížení zaměření ředitele na pedagogický proces a může být jedním z faktorů průměrných výsledků českých žáků v mezinárodních srovnávacích šetřeních. Nakonec nejen z tzv. McKinsey zprávy (2010), ale i z výsledků šetření TALIS 2013 jasně vyplývá nesprávné manažerské pojetí a je dále akcentován ředitel jako lídr pedagogického procesu.

Zde je namístě poukázat na jeden sílící trend v práci škol a jejich ředitelů. Manažerský náhled na školy stavěl jednotlivé školy i ředitele do konkurenčního postavení. Ukázalo se ovšem, že v prostředí školy je tento pohled problematický. Naopak se ukazuje, že spolupráce mezi školami, budování sítí a společných strategií se pozitivně podepisuje na výsledcích žáků (viz např. Muijs \& Rumyantseva, 2014). V pojetí společného či přímo sdíleného vedení jde o cestu ředitelů od individuální ke společné odpovědnosti, která má význam třeba pro kontinuitu rozvoje školy v okamžiku změny ředitele či jiné personální změny. V souvislosti s rozvojem spolupráce mezi školami a sítováním škol se objevuje termín hybridní leadership (Tian, 2013). Ředitelé škol ve své každodenní práci vyvažují mezi vedením (leadership) a řízením v užším slova smyslu (management), jde přitom o procesy velmi blízké, doplňující se a na sobě de facto závislé (Lazarová et al., 2015).

\section{Mezníky ve vzdělávací politice}

Skutečně významné mezníky ve vývoji vzdělávací politiky po roce 1989 byly $\mathrm{v}$ podstatě dva - reforma státní správy v roce 2000 a změny související s novým školským zákonem od ledna 2005. Po roce 2000 docházelo průběžně k legislativním změnám, které měly na ředitelskou roli vliv. Po celé toto období se ve strategických národních dokumentech objevovaly plány na standardizaci a vymezení role vedení školy včetně plánu zavést systémové vzdělávací podpory či kariérní stupně. V každém strategickém dokumentu bylo možné nalézt potvrzení vysoké autonomie ředitele školy, potřebu jeho podpory a nutnost vymezení jeho pozice. Tyto plány však vždy zůstaly pouze napsány a nebyly přes řadu dílčích snah realizovány. 


\subsection{Vznik autonomních škol a Bílá kniha}

Po roce 1989 došlo v České republice k postupné silné decentralizaci škol, která vyvrcholila v roce 2000 reformou státní správy. Krátce poté byl vydán Národní program rozvoje vzdělávání (tzv. Bílá kniha), který je významným mezníkem a zároveň prvním pokusem jasně vymezit a definovat specifickou roli ředitele školy v novém kontextu autonomních škol. Bílá kniha akcentovala systematickou přípravu ředitelů škol, práci na standardu učitele i ředitele. Záměrem bylo vymezit několik kvalifikačních kategorií pro různé učitelské pozice (např́klad výchovný poradce, vedoucí metodického sdružení a další) a rovněž vymezit kvalifikační standardy řídících pracovníků ve školství. Cílem plánovaných standardů bylo také motivovat pedagogické pracovníky k profesnímu rozvoji a podpořit tak i rozvoj celé školy (Kotásek, 2001). Kromě standardizace a popisu jednotlivých kvalifikačních kategorií cílila Bílá kniha i na vytvoření specifických vzdělávacích programů a komplexní podpory pro vedoucí školské pracovníky.

Silná autonomní pozice ředitele školy byla ukotvena s platností nového školského zákona od 1.1. 2005 (zákon 561/2004 Sb., o předškolním, základním, středním, vyšším odborném a jiném vzdělávání). Rozhodovací pravomoc se přesunula z dříve centrálně řízeného školství na nejnižší možnou úroveň, tj. př́imo na jednotlivé školy (MŠMT, 2009). Ředitel školy jako statutární zástupce začal mít ve své kompetenci utváření podoby školy, a to v oblasti zdrojů (lidských i finančních) i v oblasti kurikulární.

Za určitý specifický mezník pro ředitele škol je možné považovat začátek roku 2015, kdy uplynulo desetileté období definované $§ 32$ b), během kterého mohly vykonávat př́mou pedagogickou činnost i osoby bez požadované kvalifikace. Pokud chtěly i nadále učit, musely do konce roku 2014 zahájit studium k získání patřičné pedagogické kvalifikace (a také ho dokončit). V př́ípadě, že ředitel školy nechal dále nekvalifikované učitele vykonávat přímou pedagogickou činnost, docházelo v podstatě k porušování zákona.

Definované požadavky na ředitele školy a jeho standardizované vzdělávání nebyly uvedeny do praxe, jak je patrno i z dalšího zmiňovaného dokumentu (viz dále v textu). Realizuje se pouze oblast manažerského vzdělání jako jednoho z kvalifikačních požadavků pro vykonávání funkce ředitele školy bez další povinné kvalifikační návaznosti a dalšího specificky zacíleného manažerského vzdělávání. 


\subsection{Strategie vzdělávací politiky $\check{C} R$ do roku 2020}

Definovanou strategii vzdělávací politiky do roku 2020 považujeme za další významný mezník ve vývoji ředitelské role a opětovnou snahu roli a vzdělávání ředitelů standardizovat a nově popsat. Tento poměrně kritický dokument pojmenovává problémy, které školám komplikují jejich činnost a které také řediteli školy neumožňují optimální práci, akcentována je nejistota a nízká předvídatelnost kroků klíčových tvůrců vzdělávací politiky. Dokument rovněž otevřeně hovoří o tom, že cíle deklarované v Bílé knize nebyly splněny ani naplňovány (Strategie..., 2014).

Dokument vymezuje komplexní a jednotnou strategii pro vzdělávání v České republice, zdůvodňuje její potřebu a stanovuje priority. Rovněž klade důraz na vzdělávání pedagogických pracovníků: „Typicky je třeba zaměřit se na osvětu rodičů a společnosti, vzdělávání učitelů, ředitelů a úředníků, přehodnocení role víceletých gymnázií v systému, sjednocení vnímání kvality ve výkonech žáků i učitelů." (Strategie..., 2014, s. 17).

Strategie vymezuje specifickou roli ředitele školy a definuje nutnost vytvořit kariérní systém pro ředitele a jeho standard:

Kariérní systém pro ředitele by měl vytvořit stimulující, bezpečné a transparentní prostředí pro výběr, hodnocení a další profesní rozvoj ředitelů s důrazem na zvyšování dovedností v oblasti vedení škol k lepším výsledkům (...) vytvořit standard profese ředitele, který popíše nejdůležitější požadované dovednosti a dispozice pro kvalitní práci ředitele $\mathrm{s}$ důrazem na pedagogické vedení a na zlepšování vzdělávacího systému rozvíjením spolupráce mezi školami, provázat standard profese ředitele $s$ výběrem a hodnocením činnosti ředitele ze strany zřizovatele, resp. České školní inspekce, přičemž hlavním smyslem je poskytovat ředitelům průběžně podněty pro zlepšování jejich práce. (Strategie..., 2014, s. 26-27)

Strategie 2020 celkově věnuje značnou pozornost vzdělávání ředitelů škol, a to jak vstupnímu, tak průběžnému. $V$ rámci průběžného vzdělávání akcentuje rovněž specifickou podporu ředitele v různých fázích jeho kariéry a znovu potvrzuje jeho klíčovou roli ve vzdělávání v České republice.

Na Strategii 2020 navázal Dlouhodobý záměr vzdělávání a rozvoje vzdělávací soustavy České republiky na období 2015-2020. Tento dokument nepřichází v oblasti ředitelů škol se zásadním posunem, spíše konkretizuje v některých oblastech cíle definované ve Strategii 2020. Zaměřuje se na kariérní systém 
učitelů a ředitelů, vytvoření standardu a jeho zařazení do hodnoticích kritérií České školní inspekce (MŠMT, 2018a).

\subsection{Budoucnost - Dlouhodobý záměr vzdělávací soustavy 2019-2023}

Vzhledem ke skutečnosti, že Dlouhodobý záměr vzdělávací soustavy 2019-2023 nebyl v době psaní textu schválen, pracujeme se zveřejněným návrhem MŠMT ČR. Z hlediska pozice ředitele školy je nově akcentována role České školní inspekce, která se poprvé objevuje mezi vzdělavateli ředitelů škol. Standard ředitele je v dokumentu opět zmíněn, ale poprvé v souladu s dokumenty České školní inspekce: „Implementovat standard ředitele vycházející z hodnoticích kritérií ČŠI jako nástroj pro jejich výběr, vzdělávání a hodnocení." (MŠMT, 2018b, s. 69).

Dokument se dále věnuje podpoře ředitelů škol a jejich profesnímu rozvoji, přičemž cílí na vytvoření Stálé konference ředitelů škol, zaměřuje se na konkrétní oblasti jejich rozvoje a deleguje na ně novou odpovědnost týkající se podpůrných opatření žáků se specifickými vzdělávacími potřebami.

V této části studie jsme uvedli několik zásadních dokumentů, které považujeme za určité mezníky v pohledu na roli ředitele školy. $V$ těchto dokumentech je vždy popisována role ředitele, jeho požadované kompetence a požadavky na výkon jeho profese. Vytvoření standardu, standardizovaného vzdělávání a podpory je skutečně dlouhodobou snahou všech klíčových aktérů ve vzdělávací politice. Tato snaha nebyla nikdy úspěšně realizována. Tuto neúspěšnost strategických dokumentů vnímáme jako další faktor oslabující důvěru ředitelů ve vzdělávací politiku a myslíme si, že i proto dnes existuje prostor pro izolované podpůrné aktivity pro ředitele škol, lokální sítě a platformy. Jako př́ílad je možno uvést aktivity sdružení Trvalá obnova školy, projekt Pomáháme školám k úspěchu, Ředitel naživo, budování ředitelské akademie FranklinCovey či Vysočina Education. Všechny tyto jednotlivé aktivity mohou být ve své podstatě na vysoké úrovni, nicméně se jedná o lokální činnosti bez návaznosti na celkovou koncepci vzdělávání v České republice. 


\section{Metodologie výzkumu}

\subsection{Cíl studie a výzkumná otázka}

Cílem výzkumu je na základě studie opírající se o kvalitativní metodologické postupy popsat subjektivní vnímání proměny ředitelské role po roce 2000 a zároveň reflektovat obtížné prvky výkonu této profese v současné době.

Na základě cíle jsme definovali následující hlavní výzkumnou otázku: Jak subjektivně vnímají zkušení ředitelé proměnu své role v období po roce 2000? Tuto otázku jsme následně rozčlenili do tří podotázek, konkrétně: (1) Jaké hlavní změny cítí ředitelé škol ve své roli nyní oproti minulosti? (2) Jaké problémy řešili a řeší? (3) Jaké potřeby podpory cítí v souvislosti se změnami své role?

\subsection{Výzkumná metoda a vzorek, sběr a analýza dat}

Vzhledem ke stanovenému cíli jsme zvolili metodu skupinové diskuze neboli tzv. ohniskovou skupinu (focus group), kterou chápeme jako výzkumnou metodu, pomocí níž získáváme data za využití skupinových interakcí, které samovolně vznikají a probíhají v debatě na předem určené téma (Švaříček et al., 2007). Diskuze plasticky mapovala subjektivní názory účastníků a umožnila najít témata, která dotazovaní zkušení ředitelé vnímají jako zásadní a která se týkají vývoje, změn, problémů a potřeb v roli ředitele školy. Ohnisková skupina byla složena ze 7 osob (4 ředitelek, 3 ředitelů) z pražských základních a středních škol a byla realizována v pražské základní škole za přítomnosti tichého pozorovatele, aby bylo možné kombinovat rozhovor (záznam diskuze) a přímé pozorování (terénní zápisky pozorovatele).

Do ohniskové skupiny jsme vybrali ředitele s minimálně patnáctiletou zkušeností ve vedení školy. Tato doba byla stanovena záměrně, aby byli účastníci schopni reflektovat změny situace po zavedení nové školské legislativy v roce 2005. Ostatní parametry (věk a pohlaví ředitele, konkrétní počet obyvatel obce, vzdělání ředitele či další) nebyly brány do úvahy vzhledem k limitní velikosti ohniskové skupiny. Základní charakteristiku respondentů s uvedením jejich pseudonymů prezentuje tabulka 1 . 
Tabulka 1

Přehled respondentů

\begin{tabular}{|c|c|c|}
\hline Pseudonym & ZŠ/SŠ & Délka řídící praxe \\
\hline Dáša & ZŠ & 15 \\
\hline Petra & $Z \check{S}$ & 17 \\
\hline Karel & $Z S$ & 22 \\
\hline Jiří & $Z \check{S}$ & 15 \\
\hline Katka & SŠ & 16 \\
\hline Monika & SŠ & 16 \\
\hline Jakub & SŠ & 23 \\
\hline
\end{tabular}

Na začátku ohniskové skupiny byla připravena rámcová sktruktura, kdy byli účastníci v úvodu seznámeni s tématem a cílem výzkumu, vyslovili souhlas s nahráváním a byla dohodnuta pravidla komunikace. Pro uvedení do tématu a „rozproudění“ diskuze byli respondenti seznámeni s mezníky a významnými změnami, které jsme definovali v teoretické části této práce - tj. posilování autonomie, obsah Bílé knihy a dalších strategických dokumentů týkajících se ředitele školy a aktuálně připravovaná strategie na roky 2019-2023. Na tato témata respondenti vyjádřili svůj názor a následně již diskutovali méně řízeným způsobem. Rovněž jim byly v průběhu diskuze položeny i všechny tři dílčí výzkumné otázky (1. Jaké hlavní změny cítí ve své roli nyní oproti minulosti? 2. Jaké problémy řešili a řeší? 3. Jaké potřeby podpory cítí v souvislosti se změnami své role?). Během diskuze docházelo k usměrňování debaty ve chvíli, kdy se rozvíjela zcela mimo téma, jinak byl respondentům dán prostor vyjadřovat se k diskutovaným tématům.

Je potřeba počítat s omezeními, které každá metoda přináší. Otevřeně pojmenováváme výsledky výzkumu jako sondu do názorů a prožívání několika (celkem 7) zkušených vedoucích pedagogických pracovníků pražských škol, nikoli jako většinový názor českých ředitelů.

Diskuze byla nahrána na diktafon, opakovaně poslouchána a stěžejní výpovědi respondentů byly doslovně přepsány a následně analyzovány systémem otevřeného kódování s definováním klíčových kategorií. Otevřené kódování je nejjednodušší kódovací technikou a svým pojetím je podobné tematické analýze přítomné v každém kvalitativním výzkumu. Při procesu kódování se vytvářejí pojmy, které označují jednotky textu (datové úryvky nebo 
fragmenty). Vytvořené pojmy jsou dále kategorizovány, což znamená, že jsou seskupovány ty z nich, které se zdají příslušet ke stejnému jevu (Strauss a Corbinová, 1999; Švaříček et al., 2007). Při procesu kódování jsme dle metodologie rozčlenili získaná data na jednotlivé fragmenty (tzv. indikátory), z nich jsme vytvořili koncepty (kódy), tedy obecnější názvy, které byly dále kategorizovány na základě jednoticího kritéria (tabulka 2).

Tabulka 2

Ukázka postupu kódování dle Šed’ové (Švaříček et al., 2007)

\begin{tabular}{|c|c|c|}
\hline Úroveň & Funkce v analýze & Příklad \\
\hline Datové úryvky & Indikátory & $\begin{array}{l}\text { „S postiženými žáky pracuji přes dvacet let a nikdy } \\
\text { jsem neměla problém. Ale skutečně nechápu } \\
\text { přínos toho, kdy šesták zvyklý na malý kolektiv } \\
\text { speciální školy musel spádově k nám.“ }\end{array}$ \\
\hline Kódy & Koncepty & Subjektivní vnímání inkluze, zkušenosti \\
\hline Kategorie & Proměnné & Legislativní změny \\
\hline
\end{tabular}

K jednomu konceptu je možno přiřadit více indikátorů a následně více indikátorů vytvář́ danou proměnnou (tj. kategorii). Jednotlivé kategorie jsou podrobně popsány ve výsledkové části studie.

\section{$4 \quad$ Výsledky výzkumu}

V této části budeme (v souladu s položenými výzkumnými otázkami) postupně popisovat jednotlivé zjištěné kategorie, a to jak v rámci těchto kategorií respondenti vnímají vývoj své ředitelské role a obtížné prvky současného výkonu své profese. Reflektujeme změny po roce 2000 (změny ve vzdělávací politice a konkrétní změny $\mathrm{v}$ činnosti ředitelů škol) a dále především současné problémy, které ředitelé mají, trendy, které cítí, a podporu, kterou potřebují. Pro lepší přehlednost jsme kapitolu rozčlenili v souladu s dílčími výzkumnými otázkami na změny, problémy, trendy a podporu.

\subsection{Změny}

První z dílčích výzkumných otázek byla zaměřena na hlavní změny, které ředitelé škol cítí ve své roli nyní oproti minulosti. Účastníci v diskuzi potvrdili, že zásadním mezníkem a velkou změnou v jejich pracovní náplni byla školská autonomie a školský zákon z roku 2005. Shodli se však, že vliv 
na jejich konkrétní činnost se projevoval postupně, často až po delším časovém úseku, tj. vnímají, že se jednalo až o důsledky z těchto mezníků plynoucí. Vědí, že to byly zásadní změny, ale necítí, že by šlo o stěžejní impuls proměny postavení ředitele školy.

Respondenti shodně pojmenovali postupný nárůst odpovědnosti ředitele školy. Ředitel je podle nich vymezen dlouhodobě rámcově stejně, ale zvenčí přichází množství impulsů, požadavků a pokynů, které ovlivňují konkrétní práci, zabírají mnoho času a svým způsobem brání ředitelům být lídry pedagogického procesu.

Ředitelé uvedli, že školy ovlivňují i současné politické trendy. Jako příklad ředitelka Petra uvedla inkluzi. Uvedla, že během své pedagogické praxe měla samozřejmě mnoho zkušeností s žáky s různými potřebami podpory, ale současný tlak na společné vzdělávání vidí jako politickou objednávku:

S postiženými žáky pracuji přes dvacet let a nikdy jsem neměla problém. Ale skutečně nechápu př́nos toho, kdy šesták zvyklý na malý kolektiv speciální školy musel spádově $\mathrm{k}$ nám. Rok byl $\mathrm{v}$ naší veliké škole utrpením především pro něho, trápil se a do školy nechtěl chodit.

\subsection{Problémy}

Naším cílem bylo zjistit, jak vnímají ředitelé proměnu své role, nicméně nejvíce informací jsme získali v kategorii, kterou jsme nazvali problémy a která odpovídá druhé dílčí výzkumné otázce. Od tématu proměny role a ředitelské autonomie se diskuze stočila k současným problémům, které ředitelé pocit'ují a řeší. Můžeme je shrnout pod dva společné jmenovatele - nedostatek a nadbytek. Konkrétně: nedostatek podpory, nedostatek učitelů, nedostatek času, nadbytek byrokracie, nadbytek vykazování a nadbytek činností, které $\mathrm{z}$ úhlu pohledu ředitelů nesouvisí s pedagogickým procesem.

Jako jednu z nesmyslných činností uvedla ředitelka Dáša nutnost procházení webových stránek a vyhledávání fotografií v souvislosti s novým nařízením GDPR. Tato činnost jí zabrala čas, který by jinak ráda věnovala pedagogickému vedení: „Uvědomuji si správnost pedagogického vedení. Kde najít čas, když jsem týden procházela náš web a třídila a vyřazovala fotky? Kvůli třem rodičům. Bylo mi z toho do pláče..."

Běžnou komplikující okolností je opakované vykazování téhož údaje různým subjektům, ovšem v různé struktuře a často až nepochopitelné formě. 
Copak vzniknul zákon o svobodném př́stupu k informacím kvůli tomu, aby kdokoli mohl komplikovat naši práci? Týden jsem chystal odpovědi jednomu právníkovi. Nevěřm, že chce zlepšit kvalitu naší školy, ale já mu musel odpovídat, ačkoli polovinu údajů máme na webu. Zase mne děti neviděly na besídce, sakra... (Jiřrí)

Zásadním problémem pro účastníky výzkumu zůstává personální oblast a nedostatek pracovníků: „Víte, kdo mi učí? Inspekce se už raději neptá. A to už definitivně letos končí dva důchodci, raději vám neřeknu, kolik přesluhují." (Jakub).

Nejedná se ale pouze o nedostatek pedagogických pracovníků, i odborníci z řad nepedagogů jsou tzv. nedostatkovým zbožím, což ředitelé pocitujuj také jako velký problém a komplikaci pro svou práci, jak uvedla např́klad Monika: „Ekonomové nejsou, trnu hrůzou každý měsíc. Právě v ekonomické oblasti mám stále hlavu na špalku....

Specifický problém nedostatku pracovníků zmínil Karel, ředitel menší školy, který je na řízení v podstatě sám se svou zástupkyní, a nemůže tedy některé úkoly delegovat jako například ředitelé větších škol. Delegování by mu usnadnilo práci a umožnilo věnovat se pedagogickému procesu a pedagogickému vedení: „Vrátil jsem se včera ze zajímavého semináře. Na koho mám ale se svým počtem pracovníků povinnosti delegovat? Nemám tři zástupce jako paní lektorka." Dále také zdůraznil nárůst byrokratických požadavků, které popsal slovy: „Kdyby ale nepřibývaly hlavně ty nesmysly.“

Opakujícím se vyjádřením bylo zhoršující se postavení školy a přenášení odpovědnosti za výchovu dítěte i širší komunity na školu, stejně jako sílící nedůvěra k pedagogickým pracovníkům, tedy i k řediteli školy, jak ukazuje např́íklad výrok Katky: „Myslím, že v posledních letech hodně zasahuje do chodu škol veřejnost, především rodiče. U státních škol je to trochu problém, každý školou prošel a každý si myslí, že jí rozumí..."

\subsection{Trendy a podpora}

Třetí dílčí výzkumná otázka cílila na získání informací v oblasti podpory, kterou ředitelé škol potřebují s ohledem na změny své role. Na základě výpovědí respondentů jsme tuto část nazvali trendy a podpora, protože ředitelé škol hovořili i o budoucnosti pedagogického vedení a vedení škol a o změně ve spolupráci s některými orgány. Přestože se část respondentů neubránila pesimistickému pohledu do budoucna (například Petra: „Je stále méně věcí, 
z nichž se můžeme radovat. Bojím se vyhoření i u mladých učitelů. Poslední vzpruhou jsou žáci a přemýšlím, proč jsem u té kantořiny nezůstala."), řada z nich uvedla i pozitivní aspekty své práce a podporu (viz dále v textu).

Na otázku, jaké trendy spatřují v pedagogickém vedení a podpoře pedagogů, hovořili ředitelé pozitivně o pedagogických konzultantech ${ }^{2}$, které dva z respondentů ve škole měli; vnímají je jako konkrétní a potřebnou podporu práce učitelů, a tím i podporu pedagogického vedení: „Dnes si spolupráci pochvalují všichni učitelé. Klidně ale ted' přiznám, že jsem tomu ze začátku moc nevěřil." (Jiří).

Někteří se vyjádřili pozitivně i k rozvoji činnosti školské rady: „Bez školské rady si to neumím představit, fungujeme jako skuteční partneři. Je mi líto, když od jiných ředitelů slyším ty stesky. Třeba mám štěstí na lidi..." (Karel).

Dalším zmíněným trendem byla pokračující politizace školství zejména na zřizovatelské úrovni a nutnost udržovat vztahy s radnicí a zřizovatelem, tj. nutnost určitých politických kroků, které ředitelé vnímají jako nezbytné pro dobrý rozvoj školy: „Učitelé vůbec netuší, co se děje na radnici. Nelezu nikomu do zadnice, ale kamarádit s nimi musím. Jinak bych nic nevyjednal ne pro sebe, ale pro školu. Kdo chce s vlky býti, však to znáte..." (Jiří).

Většina účastníků také kladně hodnotí měnící se roli České školní inspekce, pojmenovávají trend jejího akcentu na pedagogický proces a pedagogické vedení, jak ukazuje např́íklad vyjádření Dáši: „Vskutku př́ijemná návštěva více hospitací, méně papírů. Bylo fajn vidět svoje lidi jinýma očima a mít možnost o těchto pohledech diskutovat. Nelze srovnat s dřívějšími papírovými válkami.“

Ve chvíli, kdy se diskuze zaměřila na plánovanou podporu ředitelů a připravované národní projekty, vyjádřili respondenti jednoznačnou nedůvěru vůči těmto projektům, například Karel uvedl: „Vůbec už tomu nevěřím. V rámci projektů, do nich jsme někdy i dotlačeni, si spíše vyměňujeme negativní zprávy, než abychom se inspirovali..."

Debata o změně ve stylech vedení ukázala, že styly vedení měnili účastníci $\mathrm{v}$ průběhu svého profesního vývoje $\mathrm{v}$ závislosti na přibývajících zkušenostech a délce řídící praxe, nikoli vzhledem $\mathrm{k}$ vnějším okolnostem.

2 Pedagogický konzultant je určitá opora pedagogického sboru, pomáhá učitelům reflektovat a zlepšovat jejich výuku a např. i plánovat profesní růst. Školy mohou konzultanty získat v rámci různých projektů neziskových organizací. 
Nebyla pojmenována jiná tendence než delegování na jiné pracovníky, sdílení v rámci týmu a později i mezi jednotlivými školami. Silným tématem pro účastníky byla i př́íprava budoucího ředitele: „Nikomu bych neradila, aby šel do konkurzu bez přípravy. Teprve ředitelské studium, já mám SVPP, mne porádně nakoplo a vím, že bych mnoha věcmi nemusela prokousávat metodou pokus-omyl. Určitě jsem pro povinnou př́pravu předem..." (Monika)

\section{Závěr}

V tomto článku nás zajímalo, jak subjektivně vnímají zkušení ředitelé proměnu své role po roce 2000 a jak reflektují obtížné prvky výkonu své profese v současné době. $V$ teoretické části jsme vymezili základní mezníky ve vzdělávací politice, které ukotvily současnou pozici škol a jejich ředitelů - především decentralizace státní správy a vysoká autonomie škol po roce 2004 v souvislosti s novým školským zákonem. Popsali jsme z těchto změn vyplývající vysoké a navyšující se nároky kladené na ředitele v oblasti lídrovské, manažerské i odborně pedagogické. Věnovali jsme se také aktuálním strategickým dokumentům a popsali již skutečně letitou snahu standardizovat a systémově uchopit roli ředitele, jeho vzdělávání, podporu a definovat jeho kariérní stupně. Tyto snahy však zůstaly pouze ve verbální rovině a podpora ředitelů není dosud systémově realizována, neexistuje standard ředitele, jeho dlouhodobá podpora ani kvalitní příprava na konkurzní rízení.

Především nás ale zajímalo, jak vnímají proměnu své role samotní zkušení ředitelé a jaké obtíže ve své roli nejvíce cítí. Ve skupinové diskuzi ředitelé potvrdili a znovu akcentovali všeobecně známý nedostatek pedagogických pracovníků, což považují za zásadní problém pro kvalitní realizaci pedagogického procesu a úspěch vzdělávacích snah. Nechybí jim ale jenom pedagogové, nedostatek pracovních sil je i u odborných nepedagogických činností, například ekonomů škol. Důležitou oblast, kterou ředitelé zmínili, je značný rozdíl mezi jednotlivými řediteli spočívající ve velikosti škol, a tedy i v možnosti delegovat některé povinnosti na zástupce či členy širšího vedení. Ředitelé malých škol nemohou mít dva či více zástupců, ale cítí, že mají stejné povinnosti jako jejich kolegové ve větších školách.

V reflexi vývoje své role se ředitelé celkově vyjadřovali spíše k současným problémům, které řeší, než aby hodnotili vývoj a postupné změny. Kromě nedostatku pracovníků shodně hovořili o nárůstu tzv. nesmyslných úkolů, které jim zabírají většinu času a znemožňují jim řídit pedagogický proces 
ve školách. Tím se v podstatě snižuje jejich zaměření na pedagogický proces a převážná náplň jejich činnosti odpovídá neoliberálnímu pojetí funkce ředitele školy (srov. Štech, 2007). Pohled ředitelů na legislativní změny byl celkově negativní a neviděli v nich žádný skutečný přínos. Měli naopak pocit, že řadu úkolů plnili bez legislativních omezení lépe (např zmíněné problémy s inkludovanými žáky). Obzvlášt' negativně hodnotili nesmyslné úkoly, které k nim přicházely mimo resort školství (tj. například důsledek nařízení GDPR) a rozčilovali se nad časově náročnými a nesmyslnými dotazy rodičů či jiných subjektů, tř́íděním fotografií apod.

Negativní vnímání jejich současné profesní role se projevilo i v rámci trendů v oblasti postavení ředitele školy v České republice, kdy za hlavní trend považují neúměrné stupňování povinností, pozitivním změnám nedůvěřují a s podporou spíše nepočítají. Všechna kladná hodnocení, která zazněla, včetně případné podpory, byla v podstatě sdělována s překvapením, jako kdyby pozitivní dopad na svou práci ředitelé neočekávali. V podstatě jediná Dáša konkrétně pozitivně zhodnotila posun v roli ČŠI. Rovněž všechny další plánované podpůrné kroky ze strany národních projektů ředitelé rovnou s nedůvěrou odmítali. $Z$ diskuze a názorů ředitelů vyplynula zakořeněná nedůvěra $\mathrm{v}$ systém a $\mathrm{v}$ možnost zlepšení podmínek. Zde vidíme také prostor pro realizaci dalších studií, které by pomohly lépe pochopit potřeby ředitelů a odhalit další příčiny nedůvěry a negativního nastavení vůči vzdělávací politice. Vzhledem k tomu, že ředitel hraje klíčovou rolí v celkové úspěšnosti pedagogického procesu, považujeme jeho negativní nastavení a nedůvěru mezi ním a národními vzdělávacími cíli za značně komplikující faktor úspěchu vzdělávání v České republice.

\section{Literatura}

Abari-Ibolya, E., \& Baráth, T. (2010). Improving school leadership in Central Europe. Budapest: Tempus Public Foundation.

Benhabani, A. (2011). Educational leaders and role of education on the efficiency of schools principals. Procedia - Social and Behavioral Sciences, 15, 9-11.

Blase, J., \& Blase, J. (2000). Effective instructional leadership: Teachers' perspective on how principals promote teaching and learning in school. Journal of Educational Administration, 38(2), 130-141.

Bolam, R., \& Van Wierigen, F. (1999). Research on educational management in Europe. Münster: Waxmann.

Briggs, A. R., \& Coleman, M. (2007). Research methods in educatioanl leadership and management. London: SAGE Publications. 
Černý, K. (2007). Budoucnost školy v percepci školského managementu. Orbis scholae, 1(3), 43-65.

Strategie vzdělávací politiky České republiky do roku 2020. (2014). Praha: MŠMT.

Dvořák, D. (2011). Pedagogické vedení školy: hledání zdrojů a obsahu pojmu. Orbis scholae, 5(3), 9-25.

Dvořák, D., \& Trunda, J. (2017). Pedagogické vedení škol: analytická zpráva. Praha: NIDV.

Hattie, J. (2011). Visible learning for teachers. United Kingdom: Taylor \& Francis.

Huber, S. G. (Ed.), (2009). School leadership international perspectives. Dortrecht: Springer.

Kaarina, M. K., \& Gonzales, N. C. (2011). The future of the physical learning environment: School facilities that support the user. Paris: OECD.

Kaščák, O., \& Pupala, B. (2012). Škola zlatých golierov: vzdelávanie v ére neoliberalizmu. Praha: SLON.

Kašparová, V., Boudová, S., Ševců, M., \& Soukup, P. (2014). Národní zpráva šetření TALIS 2013. Praha: ČS̆I.

Kotásek, J. (2001). Národní program rozvoje vzdělávání. Bílá kniha. Praha: Tauris.

Lazarová, B., Hloušková, L., Trnková, K., Pol, M., \& Lukas, J. (2015). Řízení inkluze ve škole. Brno: Masarykova univerzita.

Leithwood, K. (2005). Educational leadership: A review research. Philadelphia: The Laboratory for Student Success. Temple University.

Leithwood, K., Day, C., Sammons, P., Harris, A., \& Hopkins, D. (2006). Successful school leadership. What it is and how it influences pupil learning. Nottingham: University of Nottingham.

Leithwood, K., Sun, J., \& Pollock, K. (2017). How school leaders contribute to student success: The four parhs framework. Berlin: Springer.

Lhotková, I., Trojan, V., \& Kitzberger, J. (2012). Kompetence rídících pracovníků ve školství. Praha: Wolters Kluwer.

Lukas, J. (2009). Vztahy mezi učiteli a řediteli na základních školách - přehled relevantních výzkumů. Studia Paedagogica, 14(1), 127-145.

Klesající výsledky českého školství. (2010). Praha: McKinsey \& Company.

Moree, D. (2013). Učitelé na vlnách transformace: kultura školy před rokem 1989 a po něm. Praha: Karolinum.

MŠMT. (2009). Zpráva o vývoji českého školství od listopadu 1989 (v oblasti regionálního školství). Dostupné z http://www.msmt.cz/vzdelavani/skolstvi-v-cr/strategicke-akoncepcni-dokumenty-cerven-2009.

MŠMT. (2018a). Dlouhodobý záměr vzdělávání a rozvoje vzdělávací soustavy České republiky na období 2015-2020. Dostupné z http://www.msmt.cz/vzdelavani/skolstvi-v-cr/ dlouhodoby-zamer-vzdelavani-a-rozvoje-vzdelavaci-soustavy-3.

MŠMT. (2018b). Dlouhodobý záměr vzdělávací soustavy 2019-2023. Praha. Dostupné také z http://www.ceskaskola.cz/2018/11/dlouhodoby-zamer-vzdelavani-rozvoje.html

Muijs, D., \& Rumyantseva, N. (2014). Coopetiton in education: collaborating in a competitive environment. Journal of Educational Change, 15(1), 1-18.

Mulford, B. (2008). The leadership challenge: Improving learning in schools. Camberwell: ACER Press. 
Obdržálek, Z., \& Polák, J. (2008). Príprava školských manažérov ako klúčový predpoklad efektívnosti školy. Nitra: Univerzita Konštantina Filozofa.

Pisoňová, M. (2014). Školský manažment pre študijné odbory učitelstva a pripravu vedúcich pedagogických zamestnancov. Bratislava: Univerzita Komenského.

Píšová, M., \& Hanušová, S. (2016). Začínající učitelé a drop-out. Pedagogika, 66(4), 386-407.

Pol, M., Hloušková, L., Novotný, P., Sedláček, M., \& Zounek, J. (2004). Vnitřní a vnější souvislosti fungování školy a její kultury. Studia Paedagogica, 52(9), 47-58.

Pol, M. (2007). Škola vedená, řízená a spravovaná. Pedagogika, 57(3), 213-226.

Pont, B., Nusche, D., Moorman, H., \& Hopkins, D. (2008). Improving school leadership. Paris: OECD.

Robinson, V., Hohepa, M., \& Lloyd, C. (2009). School leadership and student outcomes: identifying what works and why: Best evidence synthesis iteration (BES). Wellington: Ministry of Education.

Sedláček, M. (2011). Pedagogické vedení školy v pojetí ředitelů základních škol. Orbis scholae 5(3), 27-42.

Schratz, M. (2011). Zlepšování kvality škol ve střední Evropě. Praha: MŠMT.

Strauss, A. L., \& Corbin, J. (1999). Základy kvalitativního výzkumu: postupy a techniky metody zakotvené teorie. Brno: Sdružení Podané ruce.

Štech, S. (2007). Profesionalita učitele v neoliberální době. Pedagogika, 57(4), 326-337.

Švařičcek, R., \& Šed'ová, K. (Eds.). (2007). Kvalitativní výzkum v pedagogických vědách. Praha: Portál.

Tian, Q. (2013). Hybrid leadership: A study of the leadership (roles and characteristics) of nine Chinese university presidents with U.S. experiences (Disertační práce). Urbana: University of Illinois at Urbana-Champaign.

Trojan, V. (2011). Vzdělávání rídicích pracovníků v českém školství: programy a hodnocení jejich obsahu účastníky. Orbis Scholae, 5(3), 107-122.

Trojan, V. (2016). Neřešené otázky profesní přípravy ředitelů škol a jejich dalšího rozvoje. Andragogická revue 1, 62-70.

Trojan, V., \& Trunda, J. (2018). Školský management v podmínkách měnící se školy. In J. Veteška, Z. Svobodová, \& M. Tureckiová, Proměny edukačních situací a jejich konceptualizace (s. 9-19). Praha: PedF UK, KAMV.

Urban, L. (2017). Sociologie. Klíčová témata a pojmy. Praha: Grada.

Veselý, A. (2013). Vzdělávací reforma v Ontariu: kritické shrnutí a inspirace pro vzdělávací politiku v ČR. Orbis scholae, 7(1), 11-28.

Veteška, J. (2016). Přehled andragogiky: úvod do studia vzdělávání a učení se dospělých. Praha: Portál.

Voda, J. (2015). Nové profesní výzvy po jmenování ředitelem školy. Pedagogika, 65(2), 177-192.

Zákon 563/2004 Sb., o předškolním, základním, středním, vyšším odborném a jiném vzdělávání. Dostupné z http://www.msmt.cz/file/38850/ 


\title{
Autoři
}

PhDr. Václav Trojan, Ph.D., Univerzita Karlova, Pedagogická fakulta, Ústav profesního rozvoje pracovníků ve školství, Magdalény Rettigové 4, 11639 Praha 1, e-mail: vaclav.trojan@pedf.cuni.cz

Mgr. Zuzana Svobodová, Ph.D., Univerzita Karlova, Pedagogická fakulta, Katedra andragogiky a managementu vzdělávání, Myslíkova 7,110 00 Praha 1, e-mail: zuzana.svobodova@pedf.cuni.cz

\section{The subjective perception of the changes of the headmaster's role and the difficult elements of the performance of this profession nowadays}

\begin{abstract}
This paper deals with the transformation of the headmaster's role after 2000 and it's subjective perception. In the theoretical part it defines the crucial milestones that newly defined the autonomous position of Czech schools and with it the autonomous role of its headmasters. It describes the strategic documents that aimed to standardize the initial and continuing education and the support of headmasters, which has never been systematically implemented. The results of qualitative research based on data from the focus group represent the subjective views of experienced directors on the development of their role, describe issues that directors perceive and trends that further determine their work. The headmaster is a fundamental factor in the success of each school and its position is specific because of the unusually high degree of curriculum and resource autonomy of the Czech school. It turns out that the gradual development and addition of additional duties and the lack of systemic support for the headmaster have created a challenging situation in which current school heads perceive a number of problems, such as lack of time to manage the pedagogical process, lack of staff and excess unnecessary bureaucracy and the intrust in the system at all.
\end{abstract}

Key words: headmaster of the school, instructional leadership, educational process, standard of headmaster of school 